Article

\title{
Opuntia Ficus-Indica L. Miller (Palma Forrageira) as an Alternative Source of Cellulose for Production of Pharmaceutical Dosage Forms and Biomaterials: Extraction and Characterization
}

\author{
Amaro César Lima de Assis 1,2, Larissa Pereira Alves ${ }^{1,2}$, João Paulo Tavares Malheiro 1,2, \\ Alana Rafaela Albuquerque Barros ${ }^{1,2}$, Edvânia Emannuelle Pinheiro-Santos ${ }^{2}$, \\ Eduardo Pereira de Azevedo ${ }^{3}$, Harley da Silva Alves ${ }^{1}(\mathbb{D}$, João Augusto Oshiro-Junior $1,2, * \mathbb{D}$ \\ and Bolívar Ponciano Goulart de Lima Damasceno ${ }^{1,2, *(D)}$ \\ 1 Graduate Program of Pharmaceutical Sciences, State University of Paraíba, \\ Campina Grande 58429-500_-PB, Brazil \\ 2 Laboratory of Development and Characterization of Pharmaceutical Products, Department of Pharmacy, \\ State University of Paraíba, Campina Grande 58429-500—PB, Brazil \\ 3 Graduate Program of Biotechnology, Laureate International Universities-Universidade Potiguar, \\ Natal 59056-000—RN, Brazil \\ * Correspondence: joaooshiro@yahoo.com.br (J.A.O.-J.); bolivarpgld@hotmail.com (B.P.G.d.L.D.); \\ Tel.: +55-83-3315-3300 (ext. 3516) (B.P.G.d.L.D.)
}

Received: 19 April 2019; Accepted: 28 June 2019; Published: 2 July 2019

\begin{abstract}
Cellulose is among the top 5 excipients used in the pharmaceutical industry. It has been considered one of the main diluents used in conventional and modern dosage forms. Therefore, different raw materials of plant origin have been evaluated as potential alternative sources of cellulose. In this context, Opuntia ficus-indica L. Miller (palma forrageira), a plant of the cactus family that has physiological mechanisms that provide greater productivity with reduced water requirements, is an interesting and unexplored alternative for extracting cellulose. By using this source, we aim to decrease the extraction stages and increase the yields, which might result in a decreased cost for the industry and consequently for the consumer. The aim of this work was to investigate the use of Opuntia ficus-indica L. Miller as a new source for cellulose extraction, therefore providing an efficient, straight forward and low-cost method of cellulose II production. The extraction method is based on the oxidation of the lignins. The obtained cellulose was identified and characterized by spectroscopic methods (FTIR and NMR), X-ray diffraction, thermal analysis (TGA-DTG and DSC) and scanning electron microscopy. The results confirmed the identity of cellulose and its fibrous nature, which are promising characteristics for its use in the industry and a reasonable substrate for chemical modifications for the synthesis of cellulose II derivatives with different physicochemical properties that might be used in the production of drug delivery systems and biomaterials.
\end{abstract}

Keywords: celullose; Opuntia ficus-indica L. Miller (palma forrageira); pharmaceutical excipients

\section{Introduction}

Cellulose is one of the most abundant renewable polymers in nature and an important component among biomass derivatives [1-3]. It consists of a homopolysaccharide of linear chain, formed by repeated units of cellobiose (two molecules of glucose) linked by glycosidic $\beta-(1-4)$ bonds [3-5]. It has a molecular formula of $\mathrm{C} 6 \mathrm{H} 10 \mathrm{O} 5$ and is commercially available as a white, fibrous, non-toxic, biodegradable, water-insoluble and relatively hygroscopic powder at $20^{\circ} \mathrm{C}$ [6-9]. 
The pharmaceutical industry has a great interest in cellulose as it is still one of the main diluents used in solid dosage forms. Furthermore, due to their low toxicity, good stability, high permeation to water, high glass transition temperature $\left(T_{\mathrm{g}}\right)$ and a good compatibility with a large number of active agents, hydrodispersible cellulose esters have been used in the production of nanostructured systems such as nanocapsules, nanofibers and micelles [10,11].

In addition, they are used in the preparation of water-soluble films for administration of drugs through buccal, sublingual, ophthalmic and topical routes. Recent reports have demonstrated the potential use of cellulose in the development of scaffolds for tissue engineering, whose application highlights its versatility and importance in the field of biomedicine [10-15].

For its use in the industry, high purity wood pulp has been the main source of cellulose [14,15]. However, alternative sources such as agroindustrial residues from biomass, as well as bacteria, tunicate (marine animals), fungi, algae and invertebrates have been previously reported in the literature [16,17]. In addition, fast growing crops that generate fibrous residues in the agribusiness, such as coconut, cotton, soybean, sisal, sugar cane, corn, rice, beans and mango lumps are generally used as plant sources. In fact, cellulose can be obtained from different parts of the plant such as leaves, fruits, stems and rigid structures like the stem and nest [7,18-22].

The source used, along with the process of extraction, isolation and purification are parameters that influence the characteristics of the obtained cellulose and, consequently, its applications [23-25]. The chemical reactivity of cellulose's hydroxyl groups $(-\mathrm{OH})$ allows the synthesis of derivatives with different physical and chemical properties. Some examples are microcrystalline cellulose and cellulose acetate [26].

In this context, Opuntia ficus-indica L. Miller (palma forrageira), which is a plant of the cactus family that has physiological mechanisms that provide greater productivity with reduced water requirement $[27,28]$, is an interesting and unexplored alternative for extracting cellulose as it seems to decrease the extraction stages and therefore obtain higher polymer yields in relation to the other sources and methods. This would decrease the costs involved in the production of cellulose, which might result in a reduced cost for the industry as well as for the final consumer.

Due to the ready availability of Opuntia ficus-indica L. Miller in the Cerrado region of Brazil and the ever-increasing interest in cellulose and its derivatives, this work aims to extract, identify and characterize cellulose from Opuntia ficus-indica L. Miller, which could be used as an alternative for pharmaceutical excipient and manufacture of biomaterials.

\section{Methods}

\subsection{Plant Material}

Samples of Opuntia ficus-indica L. Miller, variety IPA-20, were collected during the morning time at the experimental station of the National Semi-Arid Institute (INSA), $7^{\circ} 16^{\prime} 41^{\prime \prime} \mathrm{S} ; 35^{\circ} 57^{\prime} 59^{\prime \prime} \mathrm{W}$, Campina Grande, PB, Brazil. The cladodes (aerial parts of the plant) were washed with water, sectioned and dehydrated in an air circulating greenhouse (TE394/4 MP, TECNAL, São Paulo, Brazil), under controlled temperature at $60^{\circ} \mathrm{C}$ for 12 days until constant weight was achieved. The material was crushed using a rotating-knives mill coupled with a sieve of $20 \mathrm{~mm}$ mesh size (EDB-5, DeLeo-Willey, Porto Alegre, RS, Brazil). The final powdered samples were obtained in the experimental laboratories of the National Semi-Arid Institute (INSA) and the other processing stages were carried out in the Laboratory of Development and Characterization of Pharmaceutical Products (LDCPF) of the State University of Paraíba.

\subsection{Cellulose Extraction Process I: Elimination of Soluble Compounds}

For the elimination of the soluble chemical compounds, the ethanol/nitric acid method was used. This method is based on the oxidation of lignin by nitric acid. The powdered Opuntia ficus-indica L. Miller was hydrolyzed under reflux by 3 successive portions of a nitric acid: ethanol $(20: 80, v: v)$ 
mixture. The reaction mixture was changed every hour and the resulting material was washed with distilled water until the resulting washing liquid was colorless. The material was then immersed in a $1 \mathrm{~mol} \cdot \mathrm{L}^{-1} \mathrm{NaOH}$ solution for $24 \mathrm{~h}$ followed by washing and neutralization with a $10 \%$ acetic acid solution. The resulting material was dried in an oven at $105^{\circ} \mathrm{C}$ for 3 hours followed by grinding with pestle and mortar.

\subsection{Cellulose Extraction Process II: Obtention of Holocellulose}

Holocellulose is the product that results from the extraction of lignin, which consists of cellulose and hemicelluloses. The process of lignin elimination uses sodium chlorite as the main reagent and is based on the reaction between lignin and $\mathrm{ClO}_{2} / \mathrm{ClO}^{-}$, which are formed after the redox reactions of $\mathrm{ClO}_{2}^{-}$in acid medium.

Holocellulose was obtained by weighing $5.0 \mathrm{~g}$ of the crude extract of Opuntia ficus-indica L. Miller to which $100 \mathrm{~mL}$ of distilled water was added. The mixture was kept in a water bath at $75^{\circ} \mathrm{C}$ followed by the addition of $0.5 \mathrm{~mL}$ of acetic acid and $0.75 \mathrm{~g}$ of sodium chloride.

The same procedure was repeated twice, where $0.5 \mathrm{~mL}$ of acetic acid and $0.75 \mathrm{~g}$ of sodium chlorite was added at each hour. After three hours of reaction, the mixture was cooled to $10^{\circ} \mathrm{C}$, filtered and washed with distilled water at $5{ }^{\circ} \mathrm{C}$ until the fibrous residue was whitish colored. Finally, the fibrous residue was dried at $105^{\circ} \mathrm{C}$ for 3-6 h and kept in a sealed desiccator until use.

\subsection{Extraction of Cellulose}

During this process, $10.0 \mathrm{~g}$ of holocellulose was transferred to a porcelain dish to which $100 \mathrm{~mL}$ of $\mathrm{KOH}$ solution at $24 \%(w: v)$ was added. The mixture was kept under stirring using a mechanical stirrer for 15 hours at room temperature and then filtered through a glass crucible with a pre-weighed porous plate. The resulting solid residue was washed with two portions of $1 \%$ acetic acid and distilled water until the retentate was neutral followed by a final washing with ethanol. The obtained cellulose was dried at room temperature on glass plates kept away from contamination.

\subsection{Determination of the Yield of the Extraction Process}

The yield of the cellulose extraction process was determined from the mass difference between the starting material (powdered sample) and the final product corresponding to purified cellulose, as expressed in Equation (1):

$$
R(\%)=\frac{P_{\text {final }}}{P_{\text {initial }}} \times 100
$$

where $R(\%)=$ percentage yield; Pfinal = final weight of the obtained cellulose; Pinicial $=$ initial weight of the powdered Opuntia ficus-indica L. Miller.

\subsection{Identification and Characterization of Cellulose}

\subsubsection{Morphological Analysis by Scanning Electron Microscopy (SEM)}

The morphology of the samples was analyzed using a scanning electron microscope, current of $40 \mathrm{~mA}$ (Quanta 200F, Munich, Germany). The samples were previously arranged in a thin layer of carbon tape and sputter-coated with gold before morphological analysis by field-emission scanning electron microscopy (FE-SEM) (SCD500, LEICA EM, Wetzlar, Germany) with metallization time of $80 \mathrm{~s}$ and mean thickness of $10 \mathrm{~nm}$.

2.6.2. Thermoanalytical Analysis: Thermogravimetry (TG) and Differential Scanning Calorimetry (DSC)

The TG curves were obtained using a thermogravimetric module (Q600, TA-Instruments, New Castle, DE, USA). A $4.0 \mathrm{mg}$ of sample was weighed on alumina crucible and heated up to $600{ }^{\circ} \mathrm{C}$ under a nitrogen atmosphere with a flow of $50 \mathrm{~mL} \cdot \mathrm{min}^{-1}$ as purge gas and a heating rate 
of $10^{\circ} \mathrm{C} \cdot \mathrm{min}^{-1}$. Prior to the tests, the instrument was calibrated with calcium oxalate monohydrate standard under the same experimental conditions.

The DSC curves were obtained using a differential scanning calorimetric module (DSC Q20, TA Instruments, New Castle, DE, USA) under a nitrogen atmosphere with a flow of $50 \mathrm{~mL} \cdot \mathrm{min}^{-1}$, heating rate $10{ }^{\circ} \mathrm{C} \cdot \mathrm{min}^{-1}$ and a maximum temperature of $400{ }^{\circ} \mathrm{C}$. Then, $2.0 \mathrm{mg}$ of sample was weighed and sealed in an aluminum crucible. The instrument was calibrated with indium (melting of $156.6 \pm 0.2{ }^{\circ} \mathrm{C}$ ) and zinc (melting of $419.5 \pm 0.3^{\circ} \mathrm{C}$ ) standards with purity of $99.99 \%$. The heat flux and the enthalpy were adjusted using the $\Delta \mathrm{H}$ fusion of indium $\left(28.58 \pm 0.3 \mathrm{~J} \mathrm{~g}^{-1}\right)$ under the same after mentioned conditions.

\subsubsection{X-Ray Diffraction Analysis}

The diffractograms were obtained using an X-ray diffractometer (D8 Advance, Bruker, Karlsruhe, Germany) under room temperature $\left(25^{\circ} \mathrm{C}\right), \mathrm{CuK} \alpha$ radiation $(1.5418 \AA$ ) , voltage of $40 \mathrm{kV}$, current of $30 \mathrm{~mA}, 2 \theta$ values ranging from 5 to $50^{\circ} \mathrm{C}$ and speed of $0.2^{\circ} \mathrm{C} \cdot \mathrm{s}^{-1}$.

The crystalline index (CI) was calculated using Equation (2) as proposed by Segal et al. [29]:

$$
\text { C.I. }=\frac{\mathrm{I} 200-\mathrm{Iam}}{\mathrm{I} 200} \times 100
$$

where I200 is the maximum intensity (200) of the lattice diffraction; and Iam is the intensity diffraction of the amorphous peak.

\subsubsection{Fourier Transform Infrared (FT-IR) Analysis}

Holocellulose and cellulose powders were analyzed as KBr pellets, where FT-IR spectra were obtained (400-4000 $\mathrm{cm}^{-1}$ ) with 64 scans and spectral resolution of $4 \mathrm{~cm}^{-1}$ using a FT-IR spectrometer (Vertex-70, Bruker Karlsruhe, Germany).

\subsubsection{NMR Spectroscopy}

Holocellulose and cellulose were characterized using an Avance-500 NMR spectrometer (Bruker, Bremen, Germany), operating with a frequency of 500 and $125 \mathrm{MHz}$ for ${ }^{13} \mathrm{C}$ and ${ }^{1} \mathrm{H}$ analysis, respectively. Following this, $30^{\circ}$ pulses $\left(12.5 \mathrm{~ms}\right.$ for ${ }^{1} \mathrm{H}$ and $7.0 \mathrm{~ms}$ for ${ }^{13} \mathrm{C}$ ) were employed and $\mathrm{CDCl}_{3}$ was used as solvent.

\section{Results and Discussion}

\subsection{Cellulose Extraction Process}

The process of extracting cellulose from Opuntia ficus-indica L. Miller was followed by visual changes in the texture and color of the product obtained at each step of the extraction (Figure 1). Such changes were confirmed by NMR, FTIR, XRD and FE-SEM analyzes.

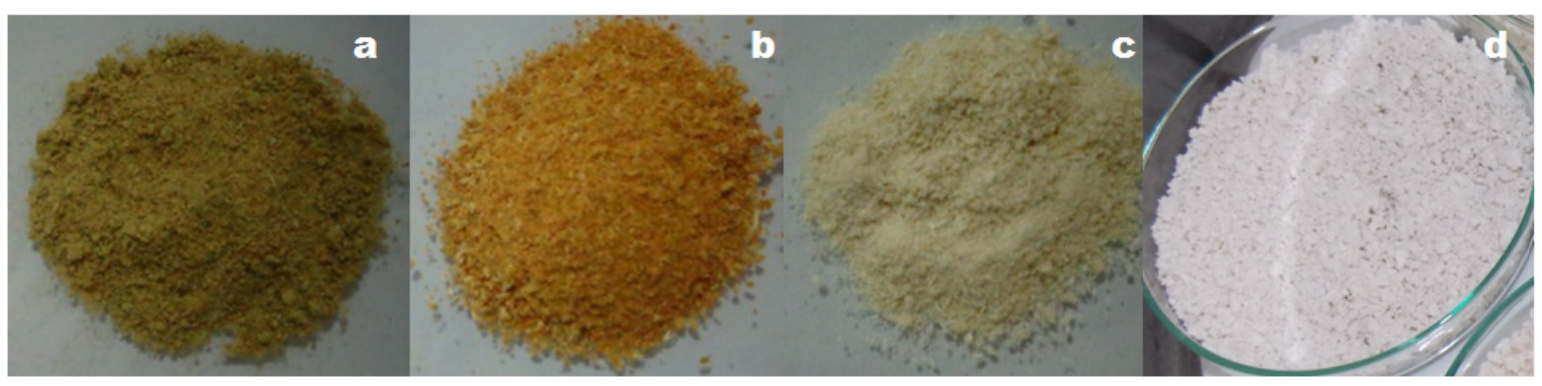

Figure 1. Technological processing of Opuntia ficus-indica L. Miller for cellulose extraction. (a) powdered plant, (b) powdered plant free of impurities, (c) holocellulose and (d) cellulose. 
Figure 1 shows that the method of extraction used in this study resulted in both purification and bleaching processes. The conversion of " $a$ " to " $b$ " occurred after removing the soluble fractions using an ethanol:nitric acid mixture (80:20, v:v), where the residue was kept in contact with $\mathrm{NaOH}$ solution. The step " $b$ " to " $c$ " represents the elimination of acid-insoluble lignins by a reaction using sodium chlorite and acetic acid. Finally, holocellulose and cellulose fractions are separated (" $c$ " to " $d$ ").

The yield of cellulose extraction from Opuntia ficus-indica L. Miller was $8.4 \pm 0.5 \%$, which is lower than the estimated cellulose content $(21 \%)$ in this plant. The succulent nature of Opuntia ficus-indica L. Miller, with its high extractable content (retentate), high levels of ashes, low dry matter content $(11.69 \pm 2.5 \%)$ and its low amount of fibers are some of factors that may have contributed to the inferior yield in relation to the total estimated amount of cellulose [30,31].

\subsection{Morphology}

The SEM micrographs of holocellulose and cellulose, both obtained from Opuntia ficus-indica L. Miller, show fibrous surfaces which is characteristic of lignocellulosic materials (Figure 2). Holocellulose's morphology is represented by a mixture of irregular, rough and fibrous-looking aggregate particles. On the other hand, cellulose appears as individualized structures with elongated morphology in the form of interconnected rods, forming organized arrangements with smooth roughness along the fiber, whose characteristics are best observed in the higher magnitude micrograph (5000x).

The occurrence of a more defined and individualized fibers in the cellulose extracted from Opuntia ficus-indica L. Miller can be attributed to the chemical and structural changes induced after chemical treatment of holocellulose, which are further evidenced by FTIR and XRD. According to Rouhou et al. [32] such modifications in the surface topography may be a result of the extraction and purification processes used to obtain the final product.
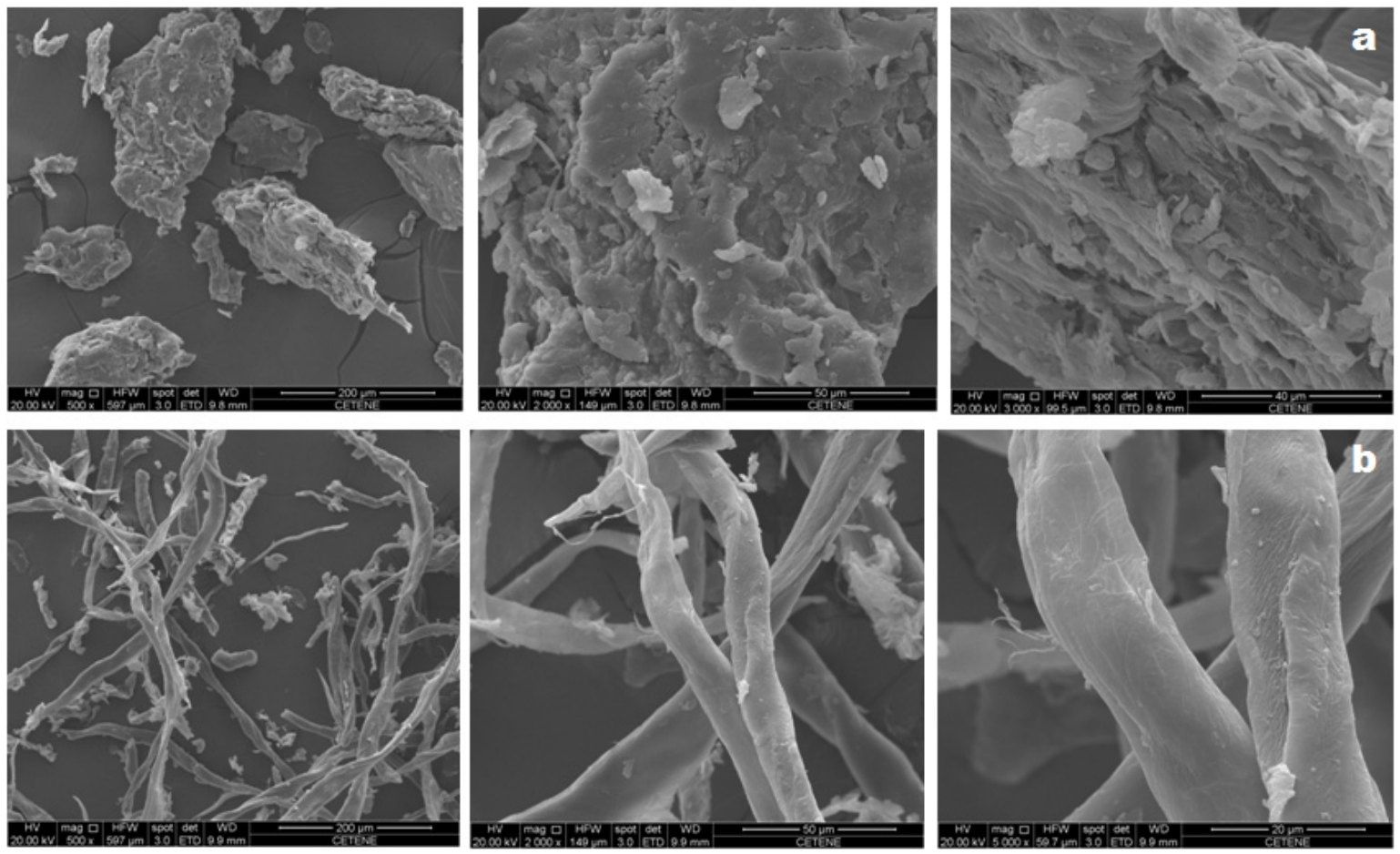

Figure 2. SEM micrographs of holocellulose (a) and cellulose (b). The magnitudes of the micrographs are $500 \times, 2000 \times$ and $5000 \times$, from left to right. 


\subsection{Thermoanalytical Analysis}

\subsubsection{Thermogravimetry}

The thermogravimetric curves and their derivatives (TGA-DTG) for cellulose (Figure 3) show its decomposition into three main events. The first event $\left(80-100^{\circ} \mathrm{C}\right)$ is attributed to the loss of water and the volatilization of low molecular weight components such as residual solvents. The second and third events are attributed to the decomposition of cellulose's polymeric chains, which are respectively represented by two mass losses: $285-345^{\circ} \mathrm{C}$ with $64.12 \%$ of mass loss and $418-452{ }^{\circ} \mathrm{C}$ with mass loss of $7.4 \%$, generating a residue of $17.2 \%$.

Figure 3 shows that the highest extent of mass loss was observed at $340{ }^{\circ} \mathrm{C}$, which is very similar to the temperature found by Jonoobi [33] for purified cellulosic fibers and by Harini et al. [3] for cellulosic fibers extracted from banana peel.

Previous report on the TGA-DTG curve for holocellulose [34] that a mass loss occurred around $220^{\circ} \mathrm{C}$ due to the thermal decomposition of the polysaccharide. On the other hand, lignocellulosic materials exhibited decomposition steps that start within the $200-260^{\circ} \mathrm{C}$ range, which are attributed to the thermal depolymerization of hemicellulose or pectin, whose processes are not observed in purified cellulose [35].

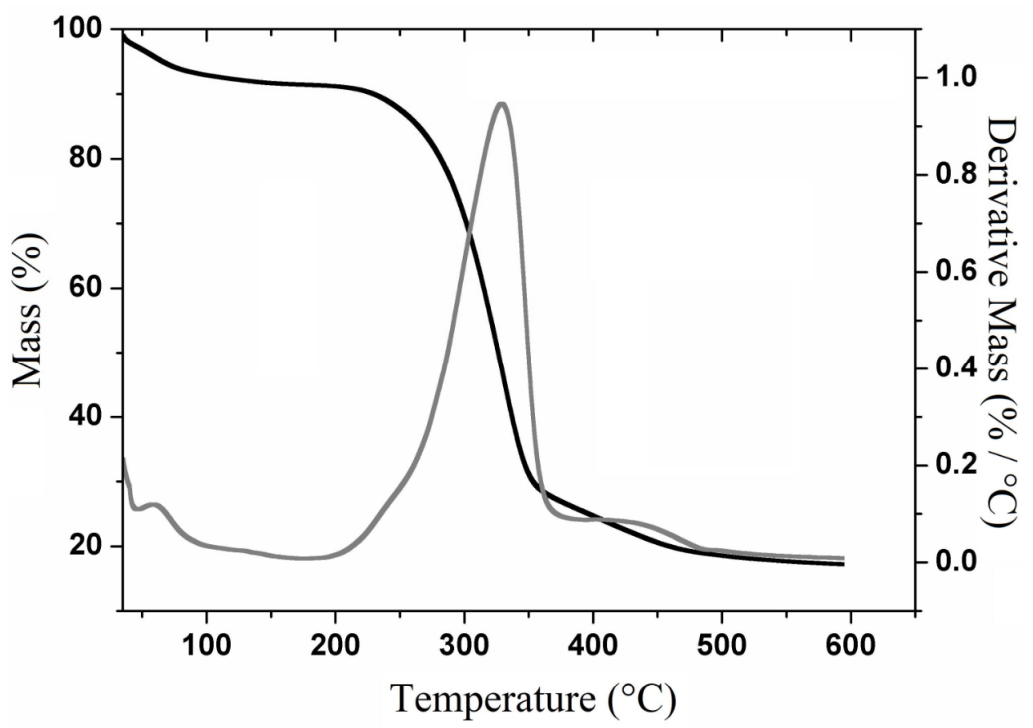

Figure 3. Thermogravimetric curves and their derivatives (TGA-DTG) curves for cellulose extracted from Opuntia ficus-indica L. Miller.

\subsubsection{Differential Scanning Calorimetry (DSC)}

The DSC curve for the cellulose extracted from Opuntia ficus-indica L. Miller presents two main events (Figure 4) as observed in the TG/DTG curves. Initially, an endotherm event with a peak near $75{ }^{\circ} \mathrm{C}$ is observed, which may be related to either the residual moisture or the inter/intramolecular bonded cellulosic chains [19].

The second event is observed in the temperature range of $280-340{ }^{\circ} \mathrm{C}$ (Figure 4) with an energy value of $140.6 \mathrm{~J} \cdot \mathrm{g}^{-1}$, which corroborates the mass loss shown in the TGA-DTG thermogram that may be related to the degradation of cellulose [36]. At temperature values beyond $300{ }^{\circ} \mathrm{C}$, the DSC curve presents a heat flux that seems to be attributed to cellulose decomposition or to a depolymerization process, with the formation of 1,6-anhydroglucose or intramolecular transglycolisation with levoglucan formation [37]. 
No characteristic events of vitreous transition $\left(T_{\mathrm{g}}\right)$ are observed. According to Almeida [38], such events may not be observed with some polymers such as cellulose where the decomposition takes place right before or parallel to the glass transition temperature, which may result in masking of such event.

As previoulsy demonstrated by Miao et al. [39], the thermal profile of holocellulose comprises two exothermic events: the first one occurring within the range of $220-315{ }^{\circ} \mathrm{C}$ (degradation of hemicelluloses) and the second around $353{ }^{\circ} \mathrm{C}$ (decomposition of the cellulose fraction). These results corroborate with our finding and might indicate the purity of the analyzed cellulose.

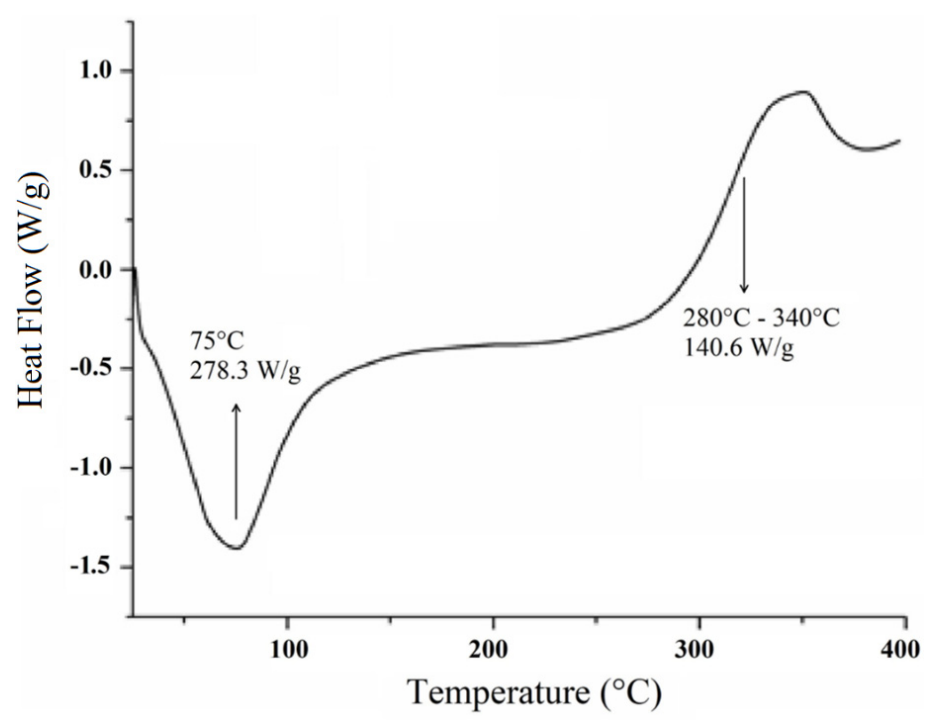

Figure 4. Differential scanning calorimetry (DSC) curve for cellulose extracted from Opuntia ficus-indica L. Miller.

\subsection{X-Ray Diffraction}

Figure 5 presents the X-ray diffractograms of holocellulose and cellulose, whose diffraction patterns characterize the structural modifications that occurred from holocellulose to cellulose. The X-ray diffraction patterns are typical of semicrystalline materials.

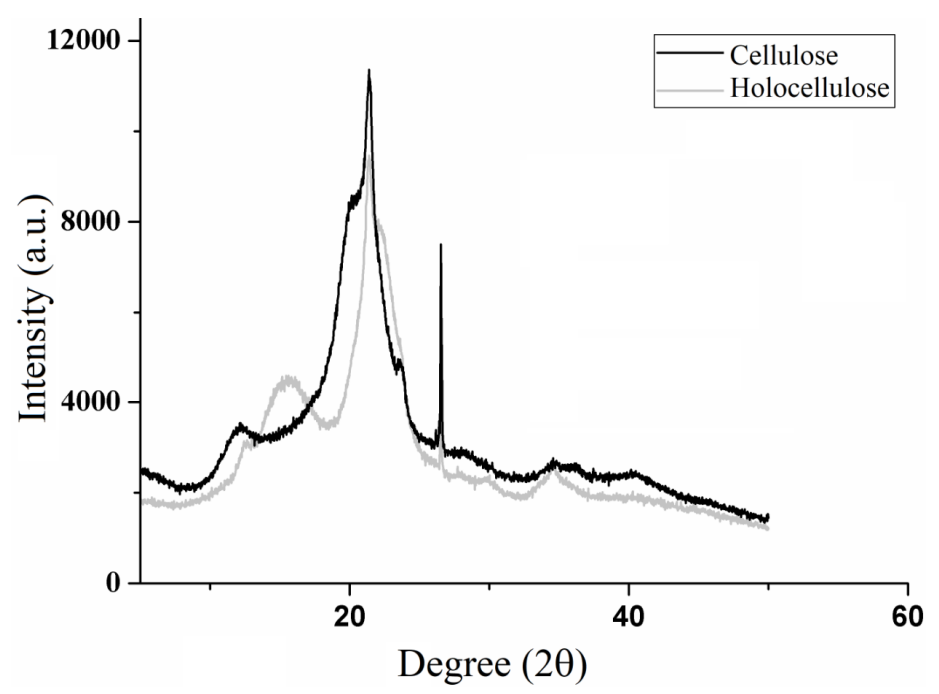

Figure 5. X-ray diffratograms of holocellulose and cellulose.

Holocellulose diffractogram presents peaks at $2 \theta=12.5,15.6,21.3,22,26.5$ and 34.4 , while cellulose diffractogram shows peaks at $2 \theta=12,20,21.2,23.6$ and 26. Previous studies have demonstrated that the diffractogram peaks for holocellulose are similar to those for cellulose I as the former is a 
mixture of cellulose and hemicelluloses [40,41]. In addition, the cellulose diffractogram reveals that it belongs to class II, as demonstrated by Astruc and colaborators [42]. The modification of the cellulose structure might have occurred due to the highly concentrated alkaline treatment $(\mathrm{KOH}$ solution at $24 \%$ $(w / v))$ [43], which causes swelling and consequently the weakening of the molecular bonds, resulting in recrystallization of the cellulose fibers [44].

Besides that, broad and diffuse peaks characteristic of amorphous regions are observed in $2 \theta=12.1$ and 15.6 for cellulose and hollocelulose, respectively. However, after hemicellulose removal, intense and narrow peaks in $2 \theta=26.5$ appears which relates to crystalline regions attributed to cellulose. In addition, the diffractograms show high intensity peaks at $2 \theta=22$ (holocellulose) and 21.4 (cellulose) that characterize semicrystalline regions.

Similar diffraction profiles were observed by Jabli et al. [45], in which the authors assigned the broad peaks around $2 \theta=15$ to amorphous regions, whereas those of greater intensity, which appeared around $2 \theta=22$, they attributed to the presence of crystalline regions within the polymer structure. According to Zhang et al. [46], these peaks around $2 \theta=22$ correspond to the packaging of the polymer chains by Van der Walls forces, which are common to most polymeric materials.

The crystalline index revealed a $64 \%$ of crystallinity for holocellulose, which is similar to those found for hollocellulose extracted from flax stem, rose stems and banana peels [42,47,48]. However, crystalline index of cellulose II was $83 \%$, which was better than that obtaneid for cellulose II extracted from sago seed shells, sugarcabe bagasse, alfa fibers and red algae waste [44,49].

\subsection{Fourier Transform Infrared (FT-IR) Spectroscopic Analysis}

The FT-IR spectrum of holocellulose (Figure 6) shows a broad band between 3650 and $3207 \mathrm{~cm}^{-1}$, which is attributed to stretching vibration of hydroxyl groups $(-\mathrm{OH})$. Bands of medium intensity were observed at $2920 \mathrm{~cm}^{-1}$, which are characteristic of $\mathrm{C}-\mathrm{H}$ stretching of $\mathrm{sp}^{3}$ carbon. In addition, the band at $1634 \mathrm{~cm}^{-1}$ results from the deformation of water molecules absorbed by the hydrophilic groups that are present along the holocellulose chain [50]. In addition, bands at 1517 and $1152 \mathrm{~cm}^{-1}$ are attributed to $C=C$ vibration of aromatic lignans and to $C-O$ stretch of hemicellulose, respectively $[46,51,52]$.

The FT-IR spectrum of cellulose (Figure 6) shows a gradual decrease in the intensity of the bands related to $-\mathrm{OH}\left(3650-3207 \mathrm{~cm}^{-1}\right), \mathrm{CH}\left(2920 \mathrm{~cm}^{-1}\right)$, the absorbed water $\left(1634 \mathrm{~cm}^{-1}\right)$ and $\mathrm{C}=\mathrm{C}$ $\left(1517 \mathrm{~cm}^{-1}\right)$, which corroborates the elimination of lignans from holocellulose [50]. In addition, the absence of band in $1737 \mathrm{~cm}^{-1}$ in the spectrum of cellulose confirms the disappearance of the carbonyl groups (hemicelluloses) [53], corroborating with the events demonstrated in the XRD after the alkaline treatment.

Finally, the decrease in the intensity of the band at $1152 \mathrm{~cm}^{-1}$ corroborates the purity of the cellulose obtained from Opuntia ficus-indica L. Miller [54,55].

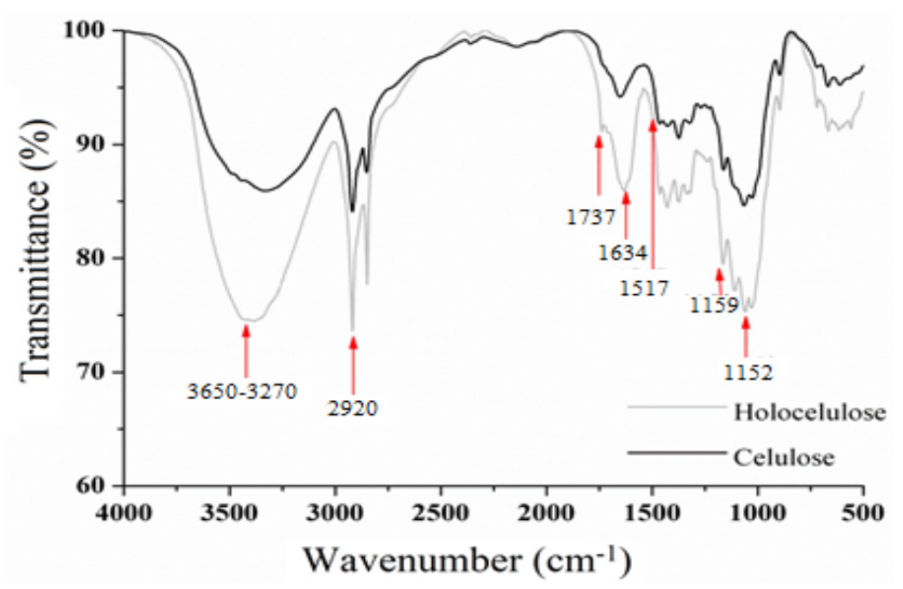

Figure 6. Fourier transform infrared (FT-IR) spectra of holocellulose and cellulose. 


\subsection{Nuclear Magnetic Resonance (NMR) Analysis}

The characterization through FT-IR and XRD of the cellulose obtained from Opuntia ficus-indica L. Miller can be corroborated through ${ }^{13} \mathrm{C}$ and ${ }^{1} \mathrm{H}$ NMR analysis. The ${ }^{1} \mathrm{H}$ NMR spectrum of the obtained cellulose shows a multiplet at 4.1-4.2 ppm (Figure 7A), which suggests the presence of osydic units in the sample. In addition, the ${ }^{13} \mathrm{C}$ resonance at $77.44 \mathrm{ppm}$ (Figure 7B) can be assigned to cellulose, which corroborates the identity of this polymer in the analyzed sample [56].

The absence of resonances in the 6.0-8.0 ppm and 100-150 ppm regions in the ${ }^{1} \mathrm{H}$ and ${ }^{13} \mathrm{C}$ spectrum, respectively, suggests that lignins are not present in the extracted sample. In addition, the absence of resonances due to carbonyls on the ${ }^{13} \mathrm{C}$ spectrum corroborates the removal of hemicellulose after the purification step of cellulose extraction [5,35].

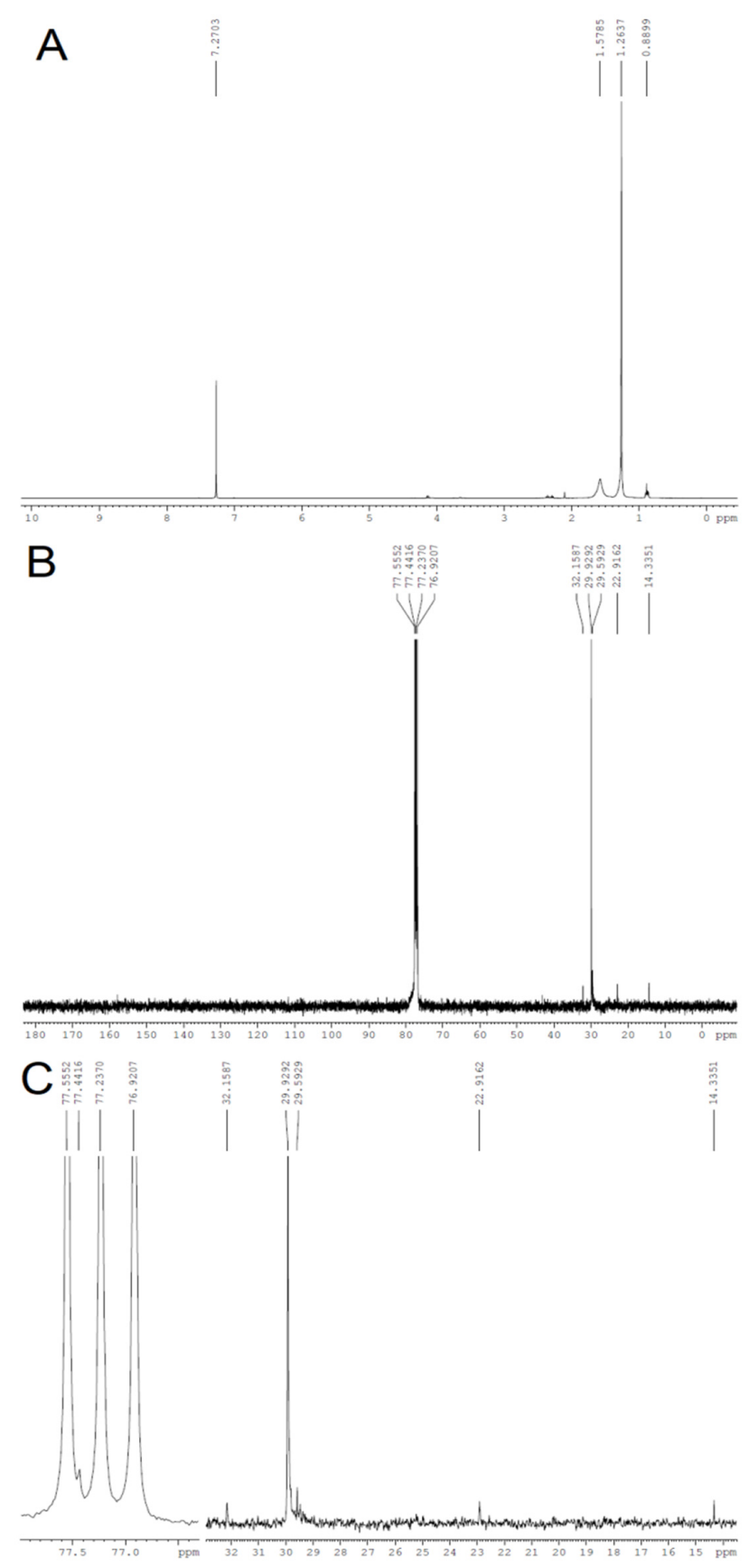

Figure 7. ${ }^{1} \mathrm{H}(\mathbf{A}),{ }^{13} \mathrm{C}(\mathbf{B})$ and amplified ${ }^{13} \mathrm{C}-\mathrm{NMR}(\mathbf{C})$ spectra of cellulose obtained from Opuntia ficus-indica L. Miller. 


\section{Conclusions}

This study showed that Opuntia ficus-indica L. Miller can be used as an alternative source of cellulose II, which is an excipient of widespread use in the pharmaceutical industry for the production of conventional and modern pharmaceutical forms as well as biomaterials. Cellulose II has better physical-chemical properties (mechanical and thermal) and stability when compared cellulose I due to antiparallel arrangement of hydrogen bonds. In addition, they can be used for producing bioethanol. The results presented in this study will support further studies aiming to optimize the extraction/purification process of cellulose from Opuntia ficus-indica L. Miller, with the purpose of obtaining a higher yield final product, which might help to reduce the costs of cellulose for the pharmaceutical industry and consequently for the consumer.

Author Contributions: Methodology, A.C.L.d.A., L.P.A., J.P.T.M., E.E.P.-S., and A.R.A.B.; formal analysis, H.d.S.A. and J.A.O.-J.; writing-original draft preparation, J.A.O.-J., B.P.G.d.L.D. and E.P.d.A.; writing—review and editing, J.A.O.-J., B.P.G.d.L.D. and E.P.d.A.; supervision, J.A.O.-J. and B.P.G.d.L.D.; funding acquisition, B.P.G.d.L.D.

Funding: We would like to thank CAPES/CNPq for the financial support.

Acknowledgments: The authors would like to thank the National Institute of the Semi-Arid (INSA) for providing Opuntia ficus-indica L. Miller and the PROCAD-Casadinho USP/UEPB for the NMR analysis. A special thanks to The Center of Strategic Technologies of the Northeast (CETENE) for providing equipment and technical support for the analyzes.

Conflicts of Interest: The authors declare no conflict of interest.

\section{References}

1. Yu, L.; Dean, K.; Li, L. Polymer blends and composites from renewable resources. Prog. Polym. Sci. 2006, 31, 576-602. [CrossRef]

2. Xiao, S.; Liu, B.; Wang, Y.; Fang, Z.; Zhang, Z. Efficient conversion of cellulose into biofuel precursor 5-hydroxymethylfurfural in dimethyl sulfoxide-ionic liquid mixtures. Bioresour. Technol. 2014, 151, 361-366. [CrossRef] [PubMed]

3. Harini, K.; Ramya, K.; Sukumar, M. Extraction of nano cellulose fibers from the banana peel and bract for production of acetyl and lauroyl cellulose. Carbohydr. Polym. 2018, 201, 329-339. [CrossRef] [PubMed]

4. Lavoine, N.; Desloges, I.; Dufresne, A.; Bras, J. Microfibrillated cellulose-Its barrier properties and applications in cellulosic materials: A review. Carbohydr. Polym. 2012, 90, 735-764. [CrossRef] [PubMed]

5. Yadav, C.; Saini, A.; Maji, P.K. Energy efficient facile extraction process of cellulose nanofibres and their dimensional characterization using light scattering techniques. Carbohydr. Polym. 2017, 165, $276-284$. [CrossRef] [PubMed]

6. Li, Q.; Renneckar, S. Molecularly thin nanoparticles from cellulose: Isolation of sub-microfibrillar structures. Cellulose 2009, 16, 1025-1032. [CrossRef]

7. Li, M.; Wang, L.J.; Li, D.; Cheng, Y.L.; Adhikari, B. Preparation and characterization of cellulose nanofibers from de-pectinated sugar beet pulp. Carbohydr. Polym. 2014, 102, 136-143. [CrossRef] [PubMed]

8. Mohamad-Haafiz, M.H.; Eichhorn, S.J.; Hassan, A.; Jawaid, M. Isolation and characterization of microcrystalline cellulose from oil palm biomass residue. Carbohydr. Polym. 2013, 93, 628-634. [CrossRef]

9. Kumar, T.S.M.; Rajini, N.; Reddy, K.O.; Rajulu, A.V.; Siengchin, S.; Ayrilmis, N. All-cellulose composite films with cellulose matrix and Napier grass cellulose fibril fillers. Int. J. Biol. Macromol. 2018, 112, 1310-1315. [CrossRef]

10. Liakos, I.L.; Iordache, F.; Carzino, R.; Scarpellini, A.; Oneto, M.; Bianchini, P.; Grumezescu, A.M.; Holban, A.M. Cellulose acetate- essential oil nanocapsules with antimicrobial activity for biomedical applications. Coll. Surf. B Biointerfaces 2018, 172, 471-479. [CrossRef]

11. Son, W.K.; Youk, J.H.; Park, W.H. Antimicrobial cellulose acetate nanofibers containing silver nanoparticles. Carbohydr. Polym. 2006, 65, 430-434. [CrossRef]

12. Bunge, K.E.; Dezzutti, C.S.; Rohan, L.C.; Hendrix, C.W.; Marzinke, M.A.; Richardson-Harman, N.; Moncla, B.J.; Devlin, B.; Meyn, L.A.; Spiegel, H.M.; et al. A phase 1 trial to assess the safety, acceptability, pharmacokinetics, and pharmacodynamics of a novel dapivirine vaginal film. J. Acquir. Immune Defic. Syndr. 2016, 71, 498-505. [CrossRef] [PubMed] 
13. Barud, H.G.; Barud, H.S.; Cavicchioli, M.; Amaral, T.S.; Oliveria-Junior, O.B.; Santos, M.D.; Petersen, A.L.O.A.; Celes, F.; Borges, V.M.; Oliverira, C.I.; et al. Preparation and characterization of a bacterial cellulose/silk fibroin sponge scaffold for tissue regeneration. Carbohydr. Polym. 2015, 128, 41-51. [CrossRef] [PubMed]

14. Maheswari, C.U.; Reddy, K.O.; Muzenda, E.; Guduri, B.R.; Rajulu, A.V. Extraction and characterization of cellulose microfibrils from agricultural residue—Cocos nucifera L. Biomass Bioenerg. 2012, 46, 555-563. [CrossRef]

15. Kouadri, I.; Satha, H. Extraction and characterization of cellulose and cellulose nanofibers from Citrullus colocynthis seeds. Ind. Crops Prod. 2018, 124, 787-796. [CrossRef]

16. Da Cruz, A.C.; Meireles, C.S.; Ribeiro, S.D.; Filho, R.G.; Assunção, R.M.N.; Cerqueira, D.A.; Zeni, M.; Poletto, P. Utilização do acetato de celulose produzido a partir da celulose extraída do caroço de manga como matriz para produção de sistemas microparticulados. Quim. Nova. 2011, 34, 385-389. [CrossRef]

17. Chen, J.; Xu, J.; Wang, K.; Cao, S.; Sun, R. Cellulose acetate fibers prepared from different raw materials with rapid synthesis method. Carbohydr. Polym. 2016, 137, 685-692. [CrossRef] [PubMed]

18. Kamel, S.; Ali, N.; Jahangir, K.; Shah, S.M.; El-Gendy, A.A. Pharmaceutical significance of cellulose: A review. Express Polym. Lett. 2008, 2, 758-778. [CrossRef]

19. Viera, R.G.P.; Filho, G.R.; Assunção, R.M.N.; Carla, C.; Vieira, J.G.; Oliveira, G.S. Synthesis and characterization of methylcellulose from sugar cane bagasse cellulose. Carbohydr. Polym. 2007, 67, 182-189. [CrossRef]

20. Lima, C.S.S.; Conceição, M.M.; Silva, F.L.H.; Lima, E.E.; Conrado, L.S.; Leão, D.A.S. Characterization of acid hydrolysis of sisal. Appl. Energy 2013, 102, 254-259. [CrossRef]

21. Flauzino-Neto, W.P.; Silvério, H.A.; Dantas, N.O.; Pasquini, D. Extraction and characterization of cellulose nanocrystals from agro-industrial residue-Soy hulls. Ind. Crops Prod. 2013, 42, 480-488. [CrossRef]

22. Cudjoe, E.; Hunsen, M.; Xue, Z.; Way, A.E.; Barrios, E.; Olson, R.A.; Hore, M.J.A.; Rowan, S.J. Miscanthus giganteus: A commercially viable sustainable source of cellulose nanocrystals. Carbohydr. Polym. 2017, 155, 230-241. [CrossRef] [PubMed]

23. Tejado, A.; Peña, C.; Labidi, J.; Echeverria, J.M.; Mondragon, I. Physico-chemical characterization of lignins from different sources for use in phenol-formaldehyde resin synthesis. Bioresour. Technol. 2007, 98, 1655-1663. [CrossRef] [PubMed]

24. Zimmermann, T.; Bordeanu, N.; Strub, E. Properties of nanofibrillated cellulose from different raw materials and its reinforcement potential. Carbohydr. Polym. 2010, 79, 1086-1093. [CrossRef]

25. Taflick, T.; Schwendler, L.A.; Rosa, S.M.L.; Bica, C.I.D.; Nachtigall, S.M.B. Cellulose nanocrystals from acacia bark-Influence of solvent extraction. Int. J. Biol. Macromol. 2017, 101, 553-561. [CrossRef]

26. Wang, W.; Liang, T.; Bai, H.; Hong, W.; Liu, X. All cellulose composites based on cellulose diacetate and nanofibrillated cellulose prepared by alkali treatment. Carbohydr. Polym. 2018, 179, 297-304. [CrossRef] [PubMed]

27. Pereiraz, E.M.; Hevilásio, F.; Pereira, F.; Lins, H.A.; De, J.R.T. Fontes de esterco e concentrações de nutrientes na solução nutritiva na produção e qualidade de brotos de palma forrageira sources of manure and nutrient concentrations in the nutrient solution on yield and quality of forage cactus buds. Revista Verde de Agroecologia e Desenvolvimento Sustentável 2012, 7, 226-231.

28. Bayar, N.; Kriaa, M.; Kammoun, R. Extraction and characterization of three polysaccharides extracted from Opuntia ficus indica cladodes. Int. J. Biol. Macromol. 2016, 92, 441-450. [CrossRef]

29. Segal, L.; Creely, J.J.; Martin, A.E.; Conrad, C.M. An empirical method for estimating the degree of crystallinity of native cellulose using the X-ray diffractometer. Text. Res. J. 1959, 29, 786-794. [CrossRef]

30. Ramos, J.P.F.; Leite, M.L.; de Oliveira-Junior, S.; Nascimento, J.P.; Santos, E.M. Crescimento vegetativo de Opuntia ficus-indica em diferentes espaçamentos de plantio. Revista Caatinga 2011, 24, 41-48.

31. Tosto, M.S.L.; Araújo, G.G.L.; Oliveira, R.L.; Bagaldo, A.R.; Dantas, F.R.; Menezes, D.R.; Chagas, E.C.O. Composição química e estimativa de energia da palma forrageira e do resíduo desidratado de vitivinícolas. Rev. Bras. Saúde Prod. 2007, 8, 239-249.

32. Rouhou, M.C.; Abdelmoumen, S.; Thomas, S.; Attia, H.; Ghorbel, D. Use of green methods in the extraction of dietary fibers from cactus rackets (Opuntia ficus indica): Structural and microstructural studies. Int. J. Biol. Macromol. 2018, 116, 901-910. [CrossRef] [PubMed]

33. Jonoobi, M.; Khazaeian, A.; Tahir, P.; Azry, S.; Oksman, K. Characteristics of cellulose nanofibers isolated from rubberwood and empty fruit bunches of oil palm using chemo-mechanical process. Cellulose 2011, 4, 1085-1095. [CrossRef] 
34. Haykiri-Acma, H.; Yaman, S.; Kucukbayrak, S. Comparison of the thermal reactivities of isolated lignin and holocellulose during pyrolysi. Fuel Proc. Technol. 2010, 91, 759-764. [CrossRef]

35. Reddy, K.O.; Maheswari, C.U.; Dhlamini, M.S.; Mothudi, B.M.; Kommula, V.P.; Zhang, J.; Zhang, J.; Rajulu, A.V. Extraction and characterization of cellulose single fibers from native african napier grass. Carbohydr. Polym. 2018, 188, 85-91. [CrossRef] [PubMed]

36. Cerqueira, D.A.; Rodrigues Filho, G.; Carvalho, R.A.; Valente, A.J.M. Caracterização de acetato de celulose obtido a partir do bagaço de cana-de-açúcar por ${ }^{1}$ H-RMN. Polímeros 2010, 20, 85-91. [CrossRef]

37. Filho, G.R.; Da Cruz, S.F.; Pasquini, D.; Cerqueira, D.A.; Prado, V.D.S.; De Assunção, R.M.N. Water flux through cellulose triacetate films produced from heterogeneous acetylation of sugar cane bagasse. J. Memb. Sci. 2000, 177, 225-231. [CrossRef]

38. Almeida, E.V.R. Uso na Preparação de Acetatos e de Filmes de Acetato de Celulose/Celulise e Quitosana/Celulose. Ph.D. Thesis, Instituto de Química de São Carlos, Universidade de São Paulo, São Carlos, SP, Brasil, 2009.

39. Miao, X.; Lina, J.; Tian, F.; Li, X.; Bian, F.; Wang, J. Cellulose nanofibrils extracted from the byproduct of cotton plant. Carbohydr. Polym. 2016, 136, 841-850. [CrossRef] [PubMed]

40. Longaresia, R.H.; Menezes, A.J.; Silva, M.A.P.; Baron, D.; Mathias, S.L. The maize stem as a potential source of cellulose nanocrystal: Cellulose characterization from its phenological growth stage dependence. Ind. Crops Prod. 2019, 133, 232-240. [CrossRef]

41. Marett, J.; Aning, A.; Foster, E.J. The isolation of cellulose nanocrystals from pistachio shells via acid hydrolysis. Ind. Crops Prod. 2017, 109, 869-874. [CrossRef]

42. Astruc, J.; Nagalakshmaiah, M.; Laroche, G.; Grandbois, M.; Elkoun, S.; Robert, M. Isolation of cellulose-II nanospheres from flax stems and their physical and morphological properties. Carbohydr. Polym. 2017, 178, 352-359. [CrossRef] [PubMed]

43. Ko, S.W.; Soriano, J.P.; Unnithana, A.R.; Lee, J.Y.; Park, C.H.; Kim, C.S. Development of bioactive cellulose nanocrystals derived from dominant cellulose polymorphs I and II from Capsosiphon fulvescens for biomedical applications. Int. J. Biol. Macromol. 2018, 110, 531-539. [CrossRef] [PubMed]

44. Naduparambath, S.; Jinitha, T.V.; Shaniba, V.; Sreejith, M.P.; Aparna, K.B.; Purushothaman, E. Isolation and characterisation of cellulose nanocrystals from sago seed shells. Carbohydr. Polym. 2018, 180, 13-20. [CrossRef] [PubMed]

45. Jabli, M.; Najeh, T.; Khiari, R.; Tawfik, A.S. Physicochemical characteristics and dyeing properties of lignin-cellulosic fibers derived from Nerium oleander. J. Mol. Liquids 2018, 249, 1138-1144. [CrossRef]

46. Zhang, Z.; Zhu, M.; Zhang, D. A Thermogravimetric study of the characteristics of pyrolysis of cellulose isolated from selected biomass. Appl. Energy 2018, 220, 87-93. [CrossRef]

47. Rambo, M.K.D.; Ferreira, M.C. Determination of cellulose crystallinity of banana residues using near infrared spectroscopy and multivariate analysis. J. Braz. Chem. Soc. 2015, 1491-1499. [CrossRef]

48. Ventura-Cruz, S.; Tecante, A. Extraction and characterization of cellulose nanofibers from Rose stems (Rosa spp.). Carbohydr. Polym. 2019, 220, 53-59. [CrossRef]

49. Kassab, Z.; Ben youcef, H.; Hannache, H.; El Achab, M. Isolation of cellulose nanocrystals from various lignocellulosic materials: Physico-chemical characterization and application in polymer composites development. Mater. Today Proc. 2019, 13, 964-973. [CrossRef]

50. Feng, Y.H.; Cheng, T.; Yang, W.; Ma, P.; He, H.; Yin, X.; Yu, X. Characteristics and environmentally friendly extraction of cellulose nanofibrils from sugarcane bagasse. Ind. Crops Prod. 2018, 111, 285-291. [CrossRef]

51. Kian, L.K.; Jawaid, M.; Ariffin, H.; Alothman, O.Y. Isolation and characterization of microcrystalline cellulose from roselle fibers. Int. J. Biol. Macromol. 2017, 103, 931-940. [CrossRef]

52. Phinichka, N.; Kaenthong, S. Regenerated cellulose from high alpha cellulose pulp of steam-exploded sugarcane bagasse. J. Mater. Res. Technol. 2018, 7, 55-65. [CrossRef]

53. Carvalho, D.M.; Mosera, C.; Lindstrima, M.E.; Sevastyanova, O. Impact of the chemical composition of cellulosic materials on the nanofibrillation process and nanopaper properties. Ind. Crops Product. 2019, 127, 203-211. [CrossRef]

54. Robles-García, M.Á.; Del-Toro-Sánchez, C.L.; Márquez-Ríos, E.; Barrera-Rodríguez, A.; Aguilar, J.; Aguilar, J.A.; Reynoso-Marín, F.J.; Ceja, I.; Dórame-Miranda, R.; Rodríguez-Félix, F. Nanofibers of cellulose bagasse from Agave tequilana Weber var. azul by electrospinning: Preparation and characterization. Carbohydr. Polym. 2018, 192, 69-74. 
55. Naduparambath, S.; Purushothaman, E. Sago seed shell: Determination of the composition and isolation of microcrystalline cellulose (MCC). Cellulose 2016, 23, 1803-1812. [CrossRef]

56. Navickiene, H.M.D.; Lopes, L.M.X. Alkamides and phenethyl derivatives from aristolochia gehrtii. J. Braz. Chem. Soc. 2001, 12, 467-472. [CrossRef] 